\title{
Osteopathic Medicine and Primary

\section{Treating anemia of chronic kidney disease in the primary care setting: cardiovascular outcomes and management recommendations}

\author{
Rebecca J Schmidt* and Cheryl L Dalton
}

Address: Section of Nephrology, Department of Medicine, West Virginia University Health Sciences Center, PO Box 9165, Morgantown, WV 26506, USA

Email: Rebecca J Schmidt* - rschmidt@hsc.wvu.edu; Cheryl L Dalton - cldalton@hsc.wvu.edu

* Corresponding author

Published: 2 October 2007

Osteopathic Medicine and Primary Care 2007, I:14 doi:10.1 I86/1750-4732-I-14

This article is available from: http://www.om-pc.com/content/I/I/14

(C) 2007 Schmidt and Dalton; licensee BioMed Central Ltd.

This is an Open Access article distributed under the terms of the Creative Commons Attribution License (http://creativecommons.org/licenses/by/2.0), which permits unrestricted use, distribution, and reproduction in any medium, provided the original work is properly cited.

\begin{abstract}
Anemia is an underrecognized but characteristic feature of chronic kidney disease (CKD), associated with significant cardiovascular morbidity, hospitalization, and mortality. Since their inception nearly two decades ago, erythropoiesis-stimulating agents (ESAs) have revolutionized the care of patients with renal anemia, and their use has been associated with improved quality of life and reduced hospitalizations, inpatient costs, and mortality. Hemoglobin targets $\geq 13 \mathrm{~g} / \mathrm{dL}$ have been linked with adverse events in recent randomized trials, raising concerns over the proper hemoglobin range for ESA treatment. This review appraises observational and randomized studies of the outcomes of erythropoietic treatment and offers recommendations for managing renal anemia in the primary care setting.
\end{abstract}

\section{Background}

Anemia, a common manifestation of chronic kidney disease (CKD), results primarily from inadequate renal secretion of erythropoietin $[1,2]$. The prevalence and severity of anemia worsen steadily as CKD advances (Figure 1) [3]. More than $30 \%$ of patients already have hemoglobin (Hb) levels $<12 \mathrm{~g} / \mathrm{dL}$ by Stage $3 \mathrm{CKD}$ [3] when the estimated glomerular filtration rate (eGFR) falls below $59 \mathrm{ml} /$ $\mathrm{min} / 1.73 \mathrm{~m}^{2}$, and many patients develop anemia before their CKD is diagnosed $[3,4]$. In patients with CKD not requiring dialysis, untreated anemia increases cardiovascular risk [5-7], hospitalization [8], and all-cause mortality, [9] and diminishes health-related quality of life [10] and exercise capacity $[11,12]$. Heightened risk for progression of kidney failure has also been linked to untreated anemia of CKD. Thus, management of anemia throughout the CKD continuum is essential $[1,2,13]$.
As renal disease often remains asymptomatic until eGFR falls well below $60 \mathrm{~mL} / \mathrm{min} / 1.73 \mathrm{~m}^{2}$, CKD, as well as its attendant anemia, remains underrecognized [14-16]. Once early CKD is diagnosed, the complexities of managing multiple comorbidities, such as uncontrolled diabetes, hypertension, hyperlipidemia, and cardiac disease, can displace clinical attention from anemia [17].

Traditionally, primary care physicians (PCPs) have been less inclined to manage anemia of CKD and have often relegated anemia treatment to a nephrologist [17-19]. However, recent claims data suggest that more than $60 \%$ of commercially insured patients with CKD-related anemia are treated exclusively by PCPs $[17,19]$, whereas patients using Medicare [18] or Veterans' Administration services [20] are more likely to be managed by nephrologists prior to dialysis onset. Rapid increases in the end- 


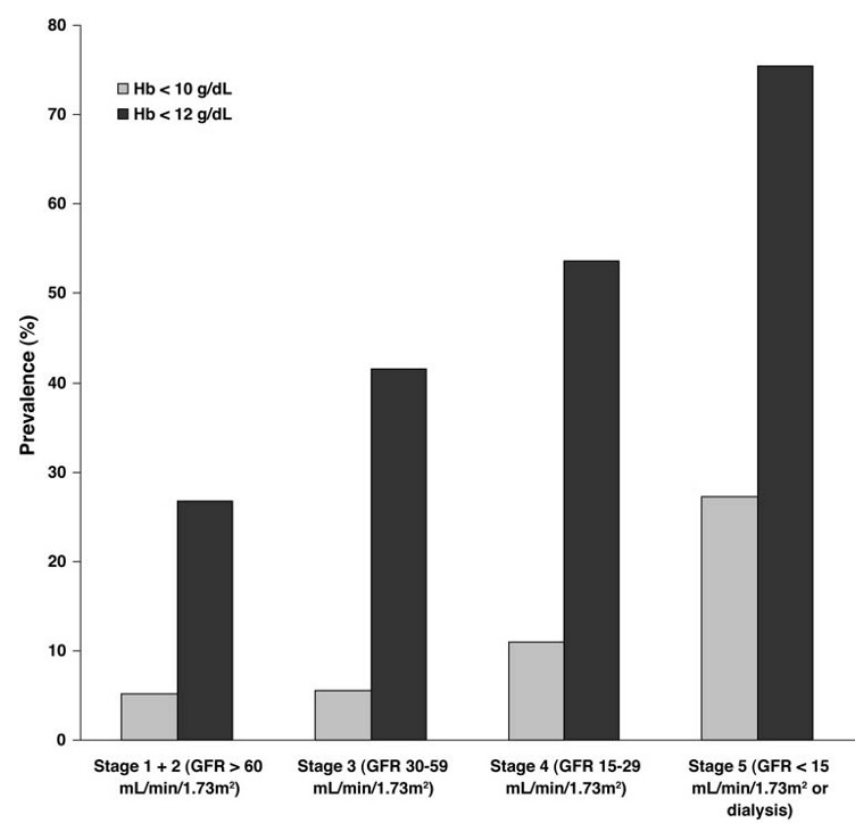

Figure I

Prevalence of anemia severity stratified by stage of chronic kidney disease. Adapted from McClellan et al., 2004 [3].

stage kidney disease population [21] have leveled off in recent years [22]; nevertheless, the aging baby boomer generation, coupled with the epidemic of obesity and diabetes, are predicted to increase the total burden of kidney disease [23]. Nephrologists bear a formidable share of the responsibility for managing advanced CKD [24] and frequently become sole providers of primary care to dialysis patients [25]. The ratio of dialysis recipients to nephrologists is predicted to exceed $160: 1$ by 2010 [24]. This impending shortage highlights the need for PCP management of early CKD and its consequences.

For patients with CKD, the risk of death from cardiovascular complications exceeds the risk of progressing to renal replacement therapy [26,27]. In a managed care study [28] of 13,796 patients with eGFR values of 15-90 mL/ $\mathrm{min} / 1.73 \mathrm{~m}^{2}, 11,278$ were in Stage 3 CKD and only 777 in Stage 4, reflecting the competing risks of cardiovascular death and CKD progression. Stage 4 CKD patients of this cohort died at a higher rate every year than age- and sexmatched controls without CKD [28].

The recognition that Stage 3 CKD patients (estimated at some 6 million in the US) are more likely to die than to live long enough to reach end stage underscores the need for CKD screening as well as the importance of maintaining a high index of suspicion of occult cardiovascular disease. PCPs are thus uniquely poised to detect and treat
CKD and its attendant risk factors before complications develop.

Evidence-based guidelines published by the National Kidney Foundation provide strategies for slowing the progression of kidney disease $[15,16,29]$, yet a significant proportion of PCPs do not recognize the importance of CKD-related anemia and its treatment [17]. In a survey of 304 US physicians, only $78 \%$ of internists and only $59 \%$ of family physicians correctly identified Stage 3-4 CKD in a hypothetical case study [30]. The potential risks and benefits of treating anemia of CKD in patients not on dialysis are presented here, with particular emphasis on cardiovascular effects, the rate of CKD progression, and the implications of recent clinical trials. Fortunately, anemia is one of the most treatment-responsive complications of CKD, and its adverse physiologic sequelae can be prevented or delayed by more timely identification and management.

\section{Review}

\section{Prevalence of anemia in CKD}

Estimates suggest that eleven percent of adults in the US population have CKD [31] - an alarming prevalence $[32,33]$ fueled primarily by the diabetes epidemic and an aging population that better survives longstanding heart disease [33]. US Renal Data System projections predict that nearly 500,000 people will have end-stage renal disease in 2010, compared with 431,000 in 2002 [34] and 286,000 in 1995 [35]. The cost of caring for CKD of all stages will soon exceed the cost of the Medicare renal replacement program itself $[26,36]$. Thus, reducing the burden of CKD and its comorbidities (including anemia) early in their course is a critical public health need.

Anemia of CKD (defined as $\mathrm{Hb} \leq 12.0 \mathrm{~g} / \mathrm{dL}$ ) becomes increasingly prevalent as kidney function declines, ranging from approximately $27 \%$ in Stage 1 to $76 \%$ in Stage 5 (Figure 1) [3,32]. In the Prevalence of Anemia in Early Renal Insufficiency study [3], 47.7\% of patients with CKD not requiring renal replacement had $\mathrm{Hb} \leq 12 \mathrm{~g} / \mathrm{dL}$. Female sex (especially before menopause) [3], African-American race [3,32,37], and diabetes [3] are independent risk factors for anemia at each stage of CKD. Anemia is less common in CKD resulting from glomerulonephritis, multiple myeloma (dysproteinemia) [3], or polycystic kidney disease $[38,39]$.

\section{Pathophysiology of anemia of CKD}

Anemia of CKD arises primarily from a progressive failure of kidney endocrine function. Peritubular cells in the kidney cortex function as oxygen sensors controlling red cell mass. Renal tissue hypoxia triggers hypoxia-inducible factor signaling, which, in turn, up-regulates erythropoietin production [40] to stimulate division and differentiation 
of red cell precursors. In anemic but otherwise healthy individuals, this feedback system restores red blood cell mass and tissue oxygenation; however, in patients with $\mathrm{CKD}$, one or more of these processes become impaired [16]. In early CKD, plasma erythropoietin levels may fall within the normal range, but show a blunted response to decreasing hematocrit. As CKD advances, the peritubular cells progressively diminish in number and function, producing insufficient erythropoietin to restore and maintain appropriate red cell mass $[2,40]$.

Anemia of CKD may reflect dysregulated erythropoietin release as well as loss of peritubular cells. One hypothesis involves down-regulation of erythropoietin production in response to a decreased GFR [41]. As functioning nephron mass decreases, kidney metabolism consumes less oxygen. Because the peritubular cells are not exposed to local hypoxia, the stimulus to increase erythropoietin production is absent and anemia and peripheral hypoxia go uncorrected [41].

Congestive heart failure (CHF) frequently complicates CKD and adversely affects erythropoiesis. Moderate-tosevere CKD [42] has been reported in $50 \%$ of patients with CHF; conversely, approximately $40 \%$ of patients with CKD have CHF [43]. Untreated CHF may contribute to anemia of CKD both by enhancing chronic inflammation [44] and by directly inducing kidney damage [45-47] (Figure 2).

\section{Consequences of untreated anemia of CKD: observational studies}

Among patients not requiring renal replacement, untreated anemia of CKD is strongly associated with cardiovascular $[6,7,46,48-50]$ and renal $[51,52]$ complications, resulting in increased hospitalizations $[8,28]$ and mortality [51].

\section{Left Ventricular Hypertrophy}

The cardiovascular system compensates for low blood oxygenation by delivering a greater volume of blood to the tissues. The necessary adaptive changes - chronic vasodilation, volume and pressure overload, increased heart rate, and increased cardiac output - ultimately result in left ventricular hypertrophy (LVH) $[2,7,13]$, whose prevalence is estimated at $39 \%$ in Stage 2 CKD, $50 \%$ in Stage 3 CKD [6,7], and 60\%-74\% in Stage 4 [7]. In a Canadian prospective study of patients with creatinine clearance $=25 \mathrm{~mL} / \mathrm{min}$ to $75 \mathrm{~mL} / \mathrm{min}[7]$, each $0.5 \mathrm{~g} / \mathrm{dL} \mathrm{Hb}$ decrease conferred a $32 \%$ increased likelihood of developing $\mathrm{LVH}$ [odds ratio $=1.32,95 \%$ confidence interval $(\mathrm{CI})$ 1.10 to $1.69, P=0.004]$. Decreasing Hb was an independent risk factor for left ventricular growth when the analysis controlled for residual kidney function [7].

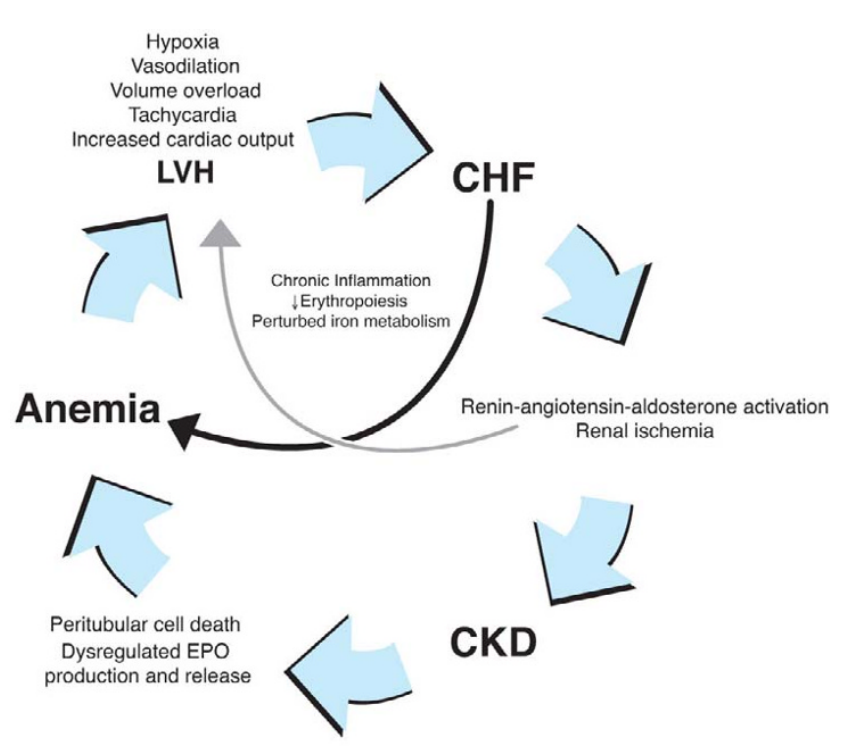

\section{Figure 2}

The cardiorenal anemia syndrome. Congestive heart failure (CHF) is a cause and consequence of CKD. First, CHF inflames the heart, liver, and vasculature, creating an influx of circulating cytokines that depress erythropoiesis and perturb iron metabolism [44]. Second, CHF directly induces kidney damage, in which GFR can deteriorate by as much as one $\mathrm{mL} /$ $\mathrm{min} / \mathrm{month}$ [45-47]. In response to reduced cardiac output, blood pressure (and renal perfusion) is maintained by activation of the renin-angiotensin-aldosterone system. Angiotensin II-mediated renal vasoconstriction and increased metabolic demands of the kidney result in renal ischemia and ultimately tubular cell death [I]. Renal cell death in turn hastens anemia through loss of endocrine function. In addition, aldosterone-induced salt and water retention leads to an increased pre-load on the heart, which increases its rate in an attempt to increase output.

\section{Congestive Heart Failure}

Chronic LVH and mechanical heart stress resulting from anemia contribute to development of congestive heart failure (CHF) [46]. Anemia has been described as a "mortality multiplier" in patients with comorbid CKD and CHF [53]. In the ANCHOR study [48] of 59,772 adults with $\mathrm{CHF}, 42.6 \%$ had anemia at baseline $(\mathrm{Hb}<12 \mathrm{~g} / \mathrm{dL}$ for women, $<13 \mathrm{~g} / \mathrm{dL}$ for men). In this cohort, anemia showed a graded, independent relationship to mortality in CHF patients, the risk of death rising from $16 \%$ for $12.0-12.9 \mathrm{~g} / \mathrm{dL}$ to $248 \%$ for $<9.0 \mathrm{~g} / \mathrm{d}$, which compared to a reference group with $\mathrm{Hb} 13.0 \mathrm{~g} / \mathrm{dL}$ to $13.9 \mathrm{~g} / \mathrm{dL}$ represents adjusted hazard ratios of 1.16 and 3.48 , respectively. $\mathrm{Hb}$ levels in relation to risk showed a J-shaped curve in this population, not all of whom had CKD; Hb levels either below $13.0 \mathrm{~g} / \mathrm{dL}$ or above $17.0 \mathrm{~g} / \mathrm{dL}$ were associated with increased risk of hospitalization and mortality [48]. 


\section{Coronary Heart Disease}

Anemia of CKD contributes to coronary ischemia by reducing oxygen delivery. In the Atherosclerosis Risk in Communities (ARIC) study [50], anemia independently predicted coronary heart disease in CKD patients. Participants with anemia and elevated serum creatinine $(\geq 1.2$ $\mathrm{mg} / \mathrm{dL}$ in women or $\geq 1.5 \mathrm{mg} / \mathrm{dL}$ in men) had increased risk for coronary heart disease over 10.5 years of followup (relative risk $=2.74,95 \%$ CI 1.42 to 5.28) [50]. Elevated creatinine without anemia did not significantly increase coronary risk (relative risk $1.20,95 \%$ CI 0.86 to 1.67) [50].

\section{Progression to Renal Replacement}

Untreated anemia of CKD is also associated with increased risk of progression to renal replacement. In a retrospective US Veterans' Affairs cohort, each $1.0 \mathrm{~g} / \mathrm{dL}$ increase in time-averaged $\mathrm{Hb}$ conferred a $26 \%$ reduction in risk for renal replacement (hazard ratio $=0.74,95 \% \mathrm{CI}$ 0.65 to 0.84 ) [51]. Among diabetic nephropathy patients in the Reduction of Endpoint in NIDDM with the Angiotensin II Antagonist Losartan (RENAAL) study [52], Hb $<11.3 \mathrm{~g} / \mathrm{dL}$ roughly doubled the risk of renal replacement onset (hazard ratio $=1.99,95 \%$ CI 1.34 to $2.95,3.4$ years mean follow-up), and every $1 \mathrm{~g} / \mathrm{dL}$ Hb decrease increased renal replacement risk by $11 \%$ [52].

\section{Treating anemia of CKD in patients not on dialysis: interventional studies}

Several interventional studies have tested the hypothesis that treating anemia of CKD with erythropoietic agents may reduce or reverse cardiac complications and retard the rate of CKD progression (Tables 1 and 2). This hypothesis reflects not only the observational associations between untreated anemia and cardiorenal morbidity, but also the physiologic connections between anemia and cardiorenal pathology (Figure 2).

Early interventional studies [47,54-59] supported the notion that treating anemia with erythropoietic agents improves cardiac and renal prognosis. Unexpectedly, the recent randomized controlled trials Correction of Hemoglobin and Outcomes in Renal Insufficiency (CHOIR) [60] and Cardiovascular Risk Reduction by Early Anemia Treatment with Epoetin (CREATE) [61] showed unforeseen increases in cardiovascular events [60] and dialysis initiation [61] among patients assigned to the highest $\mathrm{Hb}$ targets, prompting reexamination of the optimal targets and appropriate recipients of erythropoietic therapies.

The primary outcome of the US-based CHOIR study $(\mathrm{N}=$ 1432), which enrolled CKD patients with eGFR values of 15 to $50 \mathrm{~mL} / \mathrm{min} / 1.73 \mathrm{~m}^{2}$ and Hb levels $<11 \mathrm{~g} / \mathrm{dL}$, was a composite of death, myocardial infarction, hospitalization for heart failure, or stroke [60]. Patients were allo- cated to a high-Hb group (target, $13.5 \mathrm{~g} / \mathrm{dL}$ ) or a low-Hb group (target, $11.3 \mathrm{~g} / \mathrm{dL}$ ); Hb goals were achieved and maintained by titrated dosages of epoetin alfa. The trial was stopped after a mean follow-up of 16 months, when the primary outcome was reached by more patients in the high-Hb than low-Hb group (17.5\% vs. $13.5 \%, P=0.03)$. Significantly more patients in the high-Hb group reported histories of hypertension (95.8\% vs $93.2 \% ; P=0.03$ ) or coronary artery bypass grafts $(17.4 \%$ vs $13.5 \% ; P=0.05)$ at baseline, suggesting an uneven baseline cardiovascular risk burden between the groups.

The design of the international CREATE study $(\mathrm{N}=603)$ [61] was similar to CHOIR. Patients with eGFR values of $15.0 \mathrm{~mL} / \mathrm{min} / 1.73 \mathrm{~m}^{2}$ to $35.0 \mathrm{~mL} / \mathrm{min} / 1.73 \mathrm{~m}^{2}$ and $\mathrm{Hb}$ levels of $11 \mathrm{~g} / \mathrm{dL}$ to $12.5 \mathrm{~g} / \mathrm{dL}$ were randomized to receive early epoetin beta therapy to an Hb target of $13 \mathrm{~g} / \mathrm{dL}$ to 15 $\mathrm{g} / \mathrm{dL}$ or deferred epoetin beta therapy initiated when $\mathrm{Hb}$ levels fell below $10.5 \mathrm{~g} / \mathrm{dL}$. The primary endpoint was a composite of eight cardiovascular events. During an average follow-up of three years, the likelihood of a first cardiovascular event was not statistically different in the high$\mathrm{Hb}$ group than in the low-Hb group (19.3\% vs. $15.6 \%, P$ $=0.20$ ) [61]. Because the event rate in the low-Hb group was about half that expected, CREATE may be underpowered to detect differences in cardiovascular outcomes [62].

The differences between the CHOIR and CREATE results and those of earlier studies invite assessment of the factors underlying the differences and their implications for anemia treatment in the CKD population not requiring renal replacement therapy.

\section{Cardiovascular Benefits and Risks}

Data from both the CHOIR [60] and CREATE [61] studies have generated concern that $\mathrm{Hb}$ targets $>13 \mathrm{~g} / \mathrm{dL}$ are associated with increased incidence of cardiovascular complications and serious adverse events. In CHOIR, 125 endpoint events (composite of death, myocardial infarction, hospitalized CHF without dialysis, or stroke) occurred in the high-Hb group versus 97 events in the low-Hb group (HR, $1.34 ; 95 \% \mathrm{CI}, 1.03$ to $1.74 ; P=0.03$ ). CHOIR's surprising results echo those of an earlier prospective trial [63] in dialysis patients that was terminated early because of a trend toward higher rates of death and first non-fatal myocardial infarction with Hct targets of $42 \%$ versus $30 \%$. Nevertheless, the lowest mortality rates in the latter study occurred in those patients with the highest Hct (32-42\%).

In CHOIR [60], the lower Hb target (11.3 g/dL) was associated with a significantly higher incidence of myocardial infarction reported as an adverse event than the higher $\mathrm{Hb}$ target $(13.5 \mathrm{~g} / \mathrm{dL})$ (10 patients [1.5\%] vs 19 patients [3\%], $P=0.05)$. 
Table I: Effects of subcutaneous titrated dosages of erythropoietin on cardiovascular endpoints in patients with CKD not on dialysis

\begin{tabular}{|c|c|c|c|c|c|}
\hline $\begin{array}{l}\text { Reference } \\
\text { (study design) }\end{array}$ & $\begin{array}{l}\text { Level of renal function; study } \\
\text { duration }\end{array}$ & No. of pts & Treatment regimen & Endpoint & Outcome \\
\hline \multicolumn{6}{|l|}{ Left ventricular hypertrophy } \\
\hline \multirow[t]{2}{*}{ Ayus et al. [54] (uncontrolled) } & $\begin{array}{l}\mathrm{CrCl} 10-30 \mathrm{~mL} / \mathrm{min} \text { (diabetic) or } \\
20-40 \mathrm{~mL} / \mathrm{min} \text { (nondiabetic); } \\
6 \mathrm{mo}\end{array}$ & $40(\mathrm{Hb}<10 \mathrm{~g} / \mathrm{dL})$ & EPO to $12 \mathrm{~g} / \mathrm{dL}$ & Change-from-baseline LVMI & $\begin{array}{l}\text { In anemic pts, LVMI decreased vs baseline }\left(142 \text { vs } 157 \mathrm{~g} / \mathrm{m}^{2} ; P=0.007\right) \text { as } \mathrm{Hb} \\
\text { increased from } 9.1 \text { to } 11.3 \mathrm{~g} / \mathrm{dL}(P=0.001) \text {. }\end{array}$ \\
\hline & & $61(\mathrm{Hb}>10 \mathrm{~g} / \mathrm{dL})$ & Standard care & & \\
\hline \multirow[t]{2}{*}{ CREATE study [6I] (r) } & $\begin{array}{l}\text { GFR } 15-35 \mathrm{~mL} / \mathrm{min} / 1.73 \mathrm{~m}^{2}, \mathrm{Hb} \\
\text { I1.0-12.5 g/dL;3 yrs }\end{array}$ & 300 & EPO to $13-15 \mathrm{~g} / \mathrm{dL}$ & $\begin{array}{l}\text { Composite of } 8 \text { cardiovascular } \\
\text { events (primary), LVMI } \\
\text { (secondary) }\end{array}$ & $\begin{array}{l}\text { Baseline LVMl: } \\
\text { high-Hb group, } 120.3 \pm 35.0 \mathrm{~g} / \mathrm{m}^{2} \\
\text { low-Hb group, I I } 18.0 \pm 34.3 \mathrm{~g} / \mathrm{m}^{2} \\
\text { Change at year I } \\
\text { High-Hb group, }-4.6 \mathrm{~g} / \mathrm{m}^{2} \\
\text { Low-Hb group, }-3.3 \mathrm{~g} / \mathrm{m}^{2} ; P=0.59 \\
\text { Change at year } 2 \\
\text { High-Hb group, }-6.4 \mathrm{~g} / \mathrm{m}^{2} \\
\text { Low-Hb group, }-7.8 \mathrm{~g} / \mathrm{m}^{2}\end{array}$ \\
\hline & & 300 & EPO to $10.5-11.5 \mathrm{~g} / \mathrm{dL}$ & & \\
\hline \multirow[t]{2}{*}{ Levin et al. [56] (r) } & $24 \mathrm{mo}$ & 78 & Early EPO to $\mathrm{Hb} 12-14 \mathrm{~g} / \mathrm{dL}$ & Mean change-from-baseline LVMI & $\begin{array}{l}\text { Mean LVMI change from baseline: } \\
\text { early EPO, }+0.37 \mathrm{~g} / \mathrm{m}^{2} \\
\text { deferred EPO, }+5.21 \mathrm{~g} / \mathrm{m}^{2}\end{array}$ \\
\hline & & 58 & Deferred EPO to $9.0-10.5 \mathrm{~g} / \mathrm{dL}$ & & \\
\hline \multirow[t]{2}{*}{ Roger et al. [57] (r, mc, uncontrolled) } & $\begin{array}{l}\mathrm{CrCl} 15-50 \mathrm{~mL} / \mathrm{min}, \mathrm{Hb} \mid 1.0- \\
12.0 \mathrm{~g} / \mathrm{dL} \text { (in women) and I II-13 } \\
\text { g/dL (in men);2 yr or until } \\
\text { dialysis }\end{array}$ & 75 & EPO to $\mathrm{Hb} 12-13 \mathrm{~g} / \mathrm{dL}$ & Mean change-from baseline LVMI & $\begin{array}{l}\text { No statistically significant between group changes in LVMI over } 2 \text { years. } \\
\text { Based on per-protocol Hb levels: } \\
\text { Change from baseline LVMI: } \\
\text { Low Hb group }+14 \mathrm{~g} / \mathrm{m}^{2} \\
\text { High Hb group }-1 \mathrm{~g} / \mathrm{m}^{2} \text {. }\end{array}$ \\
\hline & & 80 & EPO to $\mathrm{Hb} 9-10 \mathrm{~g} / \mathrm{dL}$ & & \\
\hline
\end{tabular}

Congestive heart failure

\begin{tabular}{|c|c|c|c|c|c|}
\hline \multirow[t]{2}{*}{ Mancini et al. [77] (r) } & $\begin{array}{l}\mathrm{SrCr}<2.5 \mathrm{mg} / \mathrm{dL}, \mathrm{NYHA} \\
\text { functional class III-IV, } \\
\mathrm{Hct}<35 \% ; 3 \mathrm{mo}\end{array}$ & 15 & EPO I5 000-30 000/wk & Blood and exercise parameters & $\begin{array}{l}\text { Changes from baseline: } \\
\text { EPO group: } \\
\text { Peak VVO } \\
P<0.004 \text { II.0 to } 12.7 \mathrm{~mL} \cdot \mathrm{min}^{-1} \cdot \mathrm{kg}^{-1}, P<.05 \text { Exercise duration } 590 \text { to } 657 \mathrm{~s} \text {, } \\
\text { Placebo group: no significant changes }\end{array}$ \\
\hline & & 8 & Placebo & & \\
\hline Silverberg et al. [45] (retrospective) & $\begin{array}{l}\text { Mean NYHA 3.66, SrCr } \\
2.6 \mathrm{mg} / \mathrm{dL}, \mathrm{Hct} 30 \%, \mathrm{Hb} \\
10 \mathrm{~g} / \mathrm{dL} ;>6 \mathrm{mo}\end{array}$ & 26 & $E P O+I V$ iron to $H b \mid 2 \mathrm{~g} / \mathrm{dL}$ & $\begin{array}{l}\text { NYHA functional status, LVEF, } \\
\text { healthcare utilization }\end{array}$ & $\begin{array}{l}\text { Changes from baseline: } \\
\text { Functional status } 3.7 \text { t to } 2.7, P<0.05 \\
\text { LVEF } 28 \% \text { to } 35 \%, P<0.001 \\
\text { No. of hospitalizations/pt } 2.7 \text { to } 0.2, P<0.05 \text { ). }\end{array}$ \\
\hline \multirow[t]{2}{*}{ Silverberg et al. [47] $(r)$} & $\begin{array}{l}\text { NYHA class III-IV, LVEF } \leq 40 \% \text {, } \\
\text { Hb } 10-11.5 \mathrm{~g} / \mathrm{dL}, 50 \% \text { with } \\
\text { CKD; } 8.2 \mathrm{mo}\end{array}$ & 16 & $\mathrm{EPO}+\mathrm{IV}$ iron to $\mathrm{Hb} \geq 12.5 \mathrm{~g} / \mathrm{dL}$ & $\begin{array}{l}\text { NYHA functional status, LVEF, } \\
\text { furosemide requirements, } \\
\text { healthcare utilization }\end{array}$ & $\begin{array}{l}\text { Changes from baseline: } \\
\text { EPO + iron group: } \\
\text { NYHA class, } 42.1 \% \text { improvement LVEF: }+5.5 \% \\
\text { Length of hospitalization: }-79 \% \\
\text { Standard care group: } \\
\text { NYHA class: I } 1 \% \text { worsening } \\
\text { LVEF: }-5 \% \text { : } \\
\text { Length of hospitalization: }+58 \%\end{array}$ \\
\hline & & 16 & Standard care & & \\
\hline \multirow[t]{2}{*}{ Silverberg et al. [46] (nr) } & $\begin{array}{l}\text { NIDDM or no NIDDM plus } \\
\text { severe CHF, GFR decline } \\
>1 \mathrm{~mL} / \mathrm{min} / \mathrm{mo} ; 11.8 \mathrm{mo}\end{array}$ & 84 (NIDDM) & $\begin{array}{l}\text { EPO to } \mathrm{Hb} 12.5 \mathrm{~g} / \mathrm{dL}+\mathrm{IV} \text { iron } \\
\text { PRN }\end{array}$ & $\begin{array}{l}\text { NYHA functional class; VAS for } \\
\text { fatigue and breathlessness; LVEF }\end{array}$ & $\begin{array}{l}\text { Changes from baseline: } \\
\text { NIDDM pts: } \\
\text { NYHA functional class } 35 \% \text { improvement LVEF }+7 \% \\
\text { non-NIDDM pts: } \\
\text { NYHA functional class: } \\
32 \% \text { improvement LVEF }+12 \% \\
\text { No statistically significant differences between NIDDM and non-NIDDM. }\end{array}$ \\
\hline & & 95 (no NIDDM) & & & \\
\hline Silverberg et al. [78] (nc) & $\begin{array}{l}\text { Symptomatic CHF despite } \\
\text { optimal therapies, } \\
\mathrm{Hb}<12 \mathrm{~g} / \mathrm{dL}, 91 \% \mathrm{had} \mathrm{CKD} \\
(\mathrm{CrCl}<60 \mathrm{~mL} / \mathrm{Min}) ; 20.7 \mathrm{mo}\end{array}$ & 78 & EPO + PRN IV iron to $\mathrm{Hb} 13 \mathrm{~g} / \mathrm{dL}$ & $\begin{array}{l}\text { NYHA functional class, LVEF, } \\
\text { healthcare utilization }\end{array}$ & $\begin{array}{l}\text { Changes from baseline: (all } P<0.01 \text { ). NYHA class } 2.5 \text { (vs } 3.7 \text { ), LVEF } 37 \% \\
\text { (vs } 33 \% \text { ); No. of hospitalizations } 0.7 \text { lyear (vs } 2.7 / \text { year) }\end{array}$ \\
\hline
\end{tabular}

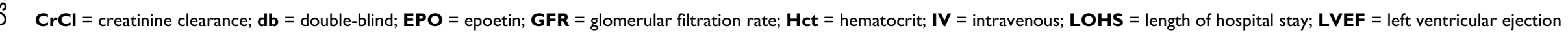

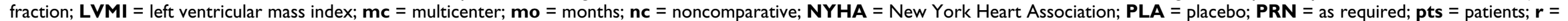
randomized; $\mathbf{S r C r}=$ serum creatinine; $\mathbf{V A S}=$ visual-analog scale; $\mathbf{w k}=$ week 
Table 2: Effects of subcutaneous titrated dosages of erythropoietin in patients not on dialysis on progression to renal replacement therapy

\begin{tabular}{llll}
\hline $\begin{array}{l}\text { Reference } \\
\text { (study design) }\end{array}$ & Level of renal function; trial duration & No. of pts & Treatment regimen \\
& & & \\
\hline $\begin{array}{l}\text { Dean et al. [55] } \\
\text { (retrospective) }\end{array}$ & $\begin{array}{l}\text { eGFR } 30-59 \mathrm{~mL} / \mathrm{min} / 1.73 \mathrm{~m}^{2}(\mathrm{n}=71) \\
\text { eGFR }<29 \mathrm{~mL} / \mathrm{min} / 1.73 \mathrm{~m}^{2}(\mathrm{n}=5 \mathrm{I})\end{array}$ & $\begin{array}{l}122 \text { Only pts } \\
\text { with } \geq 8 \text { EPO } \\
\text { doses included }\end{array}$ & $\begin{array}{l}\text { EPO }(\mathrm{Hb} \text { targets, doses not } \\
\text { specified }\end{array}$ \\
\hline $\mathrm{Hb}=10-11.9 \mathrm{~g} / \mathrm{dL}$ or $8.0-9.9 \mathrm{~g} / \mathrm{dL}$ &
\end{tabular}

Endpoint

Outcome

Change in least-squares slope Baseline eGFR $30-59 \mathrm{ml} / \mathrm{min} / \mathrm{l} .73 \mathrm{~m}^{2}$ :

$\begin{array}{lll}\text { of inverse serum creatinine } & \text { Pre-EPO rate, } \mathrm{dL} / \mathrm{mg} / \mathrm{yr} \text { : } \\ \text { clearance vs time before and } & -0.0981(95 \% \mathrm{Cl},-0.12-0.07)\end{array}$

after EPO

Post-EPO rate, dL/mg/yr: -0.06

$2(95 \% \mathrm{Cl},-0.09,-0.04)$

Baseline eGFR $<29 \mathrm{~m} / / \mathrm{min} / 1.73 \mathrm{~m}^{2}$

Post-EPO rate, dL/mg/yr: -0.0416 ( $95 \% \mathrm{Cl},-0.06,-0.02)$

Weighted mean difference, $\mathrm{dL} / \mathrm{mg} / \mathrm{yr}: 0.0493(95 \% \mathrm{Cl}, 0.0272,0.0679)$

Pe-EPO rate, dL/mg/yr: -0.0937 ( $95 \% \mathrm{Cl},-0.1 \mathrm{I},-0.08)$

Weighted mean difference, dL/mg/yr: $0.0475(95 \% \mathrm{Cl}, 0.0272,0.0679) P<0.05$

CREATE study [6I] (r) eGFR $15-35 \mathrm{~mL} / \mathrm{min} / \mathrm{l} .73 \mathrm{~m}^{2}, \mathrm{Hb}$

300

EPO to $13-15 \mathrm{~g} / \mathrm{dL}$

Time to dialysis (secondary)

Change

II.0-12.5 g/dL;3 yrs

eGFR also assessed

High-H

ligh-Hb group $-3.6 \pm 6.7 \mathrm{~mL} / \mathrm{min}$

Time to dialysis was significantly shorter in high-Hb group $(P=0.3)$

$\begin{array}{llll}\text { Gouva et al. [58] (r, mc) } & \operatorname{SrCr} 2-6 \mathrm{mg} / \mathrm{dL} \text { (eGFR not given), } \mathrm{Hb} & 300 & \text { EPO to } 10.5-11.5 \mathrm{~g} / \mathrm{dL} \\ & 95 & \text { Early EPO to } \mathrm{Hb} \geq 3 \mathrm{~g} / \mathrm{dL}\end{array}$ $9.0-11.6 \mathrm{~g} / \mathrm{dL} ; 22.5 \mathrm{mo}$

Jungers et al. [59] (c-cs) Predialysis $(\mathrm{CrCl} \leq 15 \mathrm{~mL} / \mathrm{min})$ pts (eGFR not given); 24 mo
Deferred EPO when

$20(\mathrm{Hb}<10 \mathrm{~g} / \mathrm{dL}) \quad$ EPO to $11.5 \mathrm{~g} / \mathrm{dL}$
$\begin{array}{ll}43(\mathrm{Hb}>10 \mathrm{~g} / \mathrm{dL}) & \text { Standard care } \\ 31 & \text { Standard care }\end{array}$ $\mathrm{SrCr} 2-4 \mathrm{mg} / \mathrm{dL}$ (eGFR not given),
Hematocrit $30 \% ; 28$ mo median follow-up

Doubling of baseline $\mathrm{SrCr}$ baseline $\mathrm{SrCr}$, renal placement or death

Change-from-baseline rate of time to dialysis

Composite endpoint: Early EPO pts, $29 \%$ Deferred EPO pts, $53 \% ; P=0.0078$ Renal replacement: Early EPO pts, 22\% Deferred EPO pts, $42 \% ; P=0.011$

Rate of change in creatinine clearance, $\mathrm{mL} / \mathrm{min} / 1.73 \mathrm{~m} 2 /$ month: EPO group:

dy $-0.26 \pm 0.15(P<.05)$

Standard care group

End of study $-0.57 \pm 0.44$

Time to dialysis: EPO group $16.2 \pm 11.9 \mathrm{mo}$

Standard care group $10.6 \pm 6.1 \mathrm{mo}(P<0.01)$

Doubling of baseline $\mathrm{SrCr}$

EPO, $52 \%$ of pts Standard care, $84 \%$ of pts

Nonanemic control, $60 \%$ of $P$ ts

Progression to dialysis:

Standard care, $65 \%$ of pts $(P=0.008)$

Nonanemic control, $37 \%$ of pts

$\mathrm{SrCr} 2-4 \mathrm{mg} / \mathrm{dL}$, Hematocrit $>30 \% \cdot 28 \mathrm{mo}-35$

median follow-up

Rossert et al. [66]

lothalamate GFR 25-60 mL/min; $40 \mathrm{mo}$

108

Silverberg et al. [46] (nr) Cockcroft-Gault eGFR decline $>1 \mathrm{~mL} / \mathrm{min}$ per mo; $11.8 \mathrm{mo}$

\section{O to Hct $33-35 \%$}

Nonanemic control

EPO for $\mathrm{Hb} 14-15 \mathrm{~g} / \mathrm{dL}(\mathrm{men})$

PRN EPO for $\mathrm{Hb} \mathrm{II}-12 \mathrm{~g} / \mathrm{dL}$

EPO to $\mathrm{Hb} 12.5 \mathrm{~g} / \mathrm{dL}+\mathrm{IV}$

Iron PRN

95 (no NIDDM)

a Because of labeling changes for EPO, this study terminated after 7.4 and 8.3 months of maintenance in the high and low $\mathrm{Hb}$ group, respectively.

c-cs = case-control study; $\mathbf{C H F}=$ congestive heart failure; $\mathbf{C r C l}=$ creatinine clearance; $\mathbf{d b}=$ double-blind; $\mathbf{E P O}=$ epoetin; $(\mathbf{e}) \mathbf{G F R}=($ estimated $)$ glomerular filtration rate; $\mathbf{H} \mathbf{c t}=$ hematocrit; $\mathbf{m c}=$

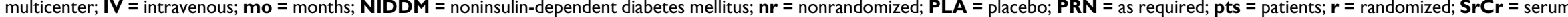
creatinine; wks = weeks 
In CREATE [61], the high-Hb group reported a greater incidence of hypertensive episodes (89 patients [30\%] vs 59 patients [20\%]; $P<0.005$ ) and headaches (31 patients $[10 \%]$ vs 16 patients $[5 \%] ; P=0.03$ ) in comparison with the low-Hb group. These findings, together with earlier reports of hypertension in ESA-treated CKD patients [58,64-67] emphasize the need to monitor blood pressure carefully during erythropoietic treatment. Current labeling of approved agents warns against beginning anemia treatment in the presence of uncontrolled hypertension $[68,69]$.

The currently ongoing Trial to Reduce Cardiovascular Events with Aranesp (TREAT) [70] is a double-blind study comparing darbepoetin alfa treatment (Hb target, $13 \mathrm{~g} /$ $\mathrm{dL}$ ) versus placebo in patients with type 2 diabetes and CKD to assess effects on cardiovascular morbidity due to acute myocardial ischemia. Placebo recipients are eligible for a rescue darbepoetin administration only if their $\mathrm{Hb}$ falls below $9 \mathrm{~g} / \mathrm{dL}$. TREAT has currently enrolled 3500 of 4000 planned patients [71] - more than CREATE and CHOIR combined. Patients will be followed until the required number of endpoint events for analysis have accrued (i.e., TREAT is an event-driven study). Its Data Safety Monitoring Board recently evaluated interim results in view of CREATE, CHOIR, and the March 2007 Food and Drug Administration (FDA) advisory [72,73] and allowed TREAT to continue [71].

\section{Renal Benefits and Risks}

When erythropoietic agents were first introduced, animal data suggesting a potential adverse effect on renal disease progression was a focus of concern. Subsequent research linked this effect with increases in blood pressure associated with rapidly rising $\mathrm{Hb}$ levels, an effect that was prevented by appropriate control of $\mathrm{Hb}$ and blood pressure. A recent review suggests that treating anemia of CKD does not hasten progression to renal replacement [74]; indeed, some studies point to possible renoprotection (Table 2). In a retrospective study of US veterans [55], the rate of decline in kidney function (least-squares slope of the reciprocal of serum creatinine) was almost halved after the onset of epoetin use as compared with the pre-treatment rate. In a 2004 randomized study [58] comparing epoetin treatment targeted to $\mathrm{Hb}>13 \mathrm{~g} / \mathrm{dL}$ with deferred treatment beginning at $<9 \mathrm{~g} / \mathrm{dL}$, roughly half as many patients required renal replacement in the early group (10 of 45 patients) as in the late group (18 of 43 patients).

In CREATE [61], although the rates of eGFR change did not differ between groups, a significantly higher rate of progression to dialysis occurred in patients assigned to a high-Hb level (13 to $15 \mathrm{~g} / \mathrm{dL}$ ) than a low-Hb level (10.5 to $11.5 \mathrm{~g} / \mathrm{dL}$ ). In CHOIR [60], in contrast, proportions of patients requiring renal replacement did not differ between groups with $\mathrm{Hb}$ targets of 11.3 or $13.5 \mathrm{~g} / \mathrm{dL}$.

There is a paucity of information on the effect of anemia treatment on measured GFR. Effects of anemia treatment on renal function were assessed by disparate methods among the studies cited in Table 2 and those in the Cochrane systematic review [67]. Discordances among renal results in CREATE, CHOIR, and previous studies point to the need for a further randomized trial of anemia therapy in which change in the rate of decline in measured GFR is a primary endpoint.

\section{Cognition and Quality of Life}

In patients on dialysis, untreated anemia can result in objective cognitive deficits [75], and treatment of anemia is associated with improved cognitive and social functioning [76]. Thus, cognitive and quality-of-life effects have also been assessed in patients at earlier stages of CKD receiving anemia treatment. A meta-analysis in this population associates erythropoietin use with improved physical function, energy, sense of well-being, and ability to work [67]. In CREATE, mean quality-of-life scores were higher in the normalized $\mathrm{Hb}$ group $(13.0 \mathrm{~g} / \mathrm{dL}$ to $15.0 \mathrm{~g} /$ $\mathrm{dL})$ than the low-Hb group $(10.5 \mathrm{~g} / \mathrm{dL}$ to $11.5 \mathrm{~g} / \mathrm{dL})$ during the first year and became similar between groups thereafter [61]. In CHOIR, quality of life did not differ between $\mathrm{Hb}$ target groups. Thus, improvement in quality of life with erythropoietic treatment may be intuitive but is not yet proven.

\section{Management of Adults with Anemia of Chronic Kidney Disease \\ Clinical Evaluation and Diagnosis}

Screening for anemia and other comorbidities is essential for patients diagnosed with Stage 3 CKD [16]. The course of CKD is often gradual (years to decades), and decline in $\mathrm{Hb}$, like decline in eGFR, may be evident only with periodic evaluation. Annual determination of renal function and $\mathrm{Hb}$ levels may suffice for slowly progressing or early CKD [16]. Patients with moderate-to-severe CKD may require more frequent $\mathrm{Hb}$ monitoring since the likelihood of anemia is greater in this population; more frequent monitoring (at least monthly) is also required during treatment with stimulants of erythropoiesis. Patients with an eGFR below $30 \mathrm{~mL} / \mathrm{min} / 1.73 \mathrm{~m}^{2}$ are considered appropriate for referral to a nephrologist, and many PCPs and nephrologists prefer a higher eGFR referral trigger as Stage 3 approaches. It is prudent to screen for anemia in CKD patients during and after acute episodes of uncontrolled comorbid disease (eg, poor glycemic control).

All patients with independent risk factors for CKD-related anemia warrant close hematologic evaluation during follow-up clinic visits. In addition, diabetic patients are twice 
as likely to develop anemia as their nondiabetic counterparts at the same level of renal function $[37,70]$, and the prevalence of anemia in patients with cardiovascular disease is also significant $[42,43]$. Patients should also be checked for malnutrition and vitamin deficiency syndromes.

A Hb level below $12.0 \mathrm{~g} / \mathrm{dL}$ in women or $13.5 \mathrm{~g} / \mathrm{dL}$ in men warrants clinical work-up for anemia (Table 3 ). In general, CKD-related anemia is normochromic and normocytic with bone marrow of normal cellularity. With impaired production and/or activity of erythropoietin, the anemia is usually hypoproliferative, as determined by the absolute reticulocyte count.

\section{Treatment}

While the propriety of treating anemia of CKD is well established to within a $\mathrm{Hb}$ target range of $11-12 \mathrm{~g} / \mathrm{dL}$, full normalization of $\mathrm{Hb}$ in these patients remains controver- sial, and benefits remain unproven. New guidelines published by the Kidney Disease Outcomes Quality Initiative (KDOQI) in August 2007 recommend a Hb target range of 11-12 g/dL for patients with CKD [29]. The CHOIR [60] and CREATE [61] studies indicate evidence of risk and no evidence of benefit from treating to Hb levels $>13.0 \mathrm{~g} / \mathrm{dL}$ as compared with $\leq 12 \mathrm{~g} / \mathrm{dL}$. A 2007 FDA advisory [72,73] recommends maintaining $\mathrm{Hb}$ within the range of 10-12 $\mathrm{g} / \mathrm{dL}$. Evidence reviewed in the KDOQI guidelines $[16,29]$ suggests that treating to maintain $\mathrm{Hb}$ at or above $11 \mathrm{~g} / \mathrm{dL}$ provides quality of life benefits without increased adverse events. Routine monitoring (preferably monthly) of blood pressure, renal function, $\mathrm{Hb}$, and iron studies is required to obtain the most effective regimen of erythropoietic therapy $[68,69]$. The current FDA advisory $[72,73]$ recommends more frequent $\mathrm{Hb}$ monitoring (twice weekly) during initial correction of anemia and after ESA dose changes.

Table 3: Management of anemia in patients with chronic kidney disease (CKD) $[16,29]$

\begin{tabular}{|c|c|}
\hline Intervention & Significance \\
\hline \multicolumn{2}{|l|}{ Identification and clinical evaluation } \\
\hline Screening & $\begin{array}{l}\text { Patients with CKD should be evaluated for the presence of anemia once GFR reaches } 60 \mathrm{~mL} / \mathrm{min} \text {. } \\
\text { Kidney function (and } \mathrm{Hb} \text { level) should be assessed in all patients with cardiovascular disease and } \\
\text { diabetes. }\end{array}$ \\
\hline \multicolumn{2}{|l|}{ Hematological work-up } \\
\hline $\mathrm{Hb}$ & $\begin{array}{l}\text { Determines severity of anemia. } \mathrm{Hb} \text { is a more reliable surrogate marker than hematocrit. Dosages } \\
\text { of erythropoietic agents are titrated to the absolute } \mathrm{Hb} \text { value, taking into account the relative } \\
\text { increase from the last dosage. }\end{array}$ \\
\hline $\begin{array}{l}\text { Complete blood count (MCH, MCV, MCHC, } \\
\text { white blood cell count, platelet count) }\end{array}$ & $\begin{array}{l}\text { Information on: potential folate and vitamin } \mathrm{B}_{12} \text { deficiency (high MCV indicative of macrocytosis); } \\
\text { iron deficiency (low } \mathrm{MCH} \text { indicative of hypochromia); and capacity of bone marrow function. }\end{array}$ \\
\hline Absolute reticulocyte count & Determination of proliferative activity \\
\hline Serum ferritin & $\begin{array}{l}\text { Assessment of iron storage reserves (target, } 200 \mathrm{ng} / \mathrm{mL} \text { ). There is little evidence to suggest } \\
\text { treating patients with levels }>500 \mathrm{ng} / \mathrm{mL} \text { is worthwhile. }\end{array}$ \\
\hline TSAT or $\mathrm{Hb}$ content in reticulocytes & Iron balance and distribution (TSAT target $>20 \%$ ). \\
\hline
\end{tabular}

\section{Treatment}

Target risk factors

Stimulants of erythropoiesis

Iron

Nutritional supplements

Androgens
Progression of CKD can be delayed by tight control of blood pressure, blood glucose, and proteinuria.

Recommended in anemic patients to maintain $\mathrm{Hb}$ levels between $11.0 \mathrm{~g} / \mathrm{dL}$ and $12.0 \mathrm{~g} / \mathrm{dL}$. Monthly follow-up is required to ensure the regimen does not raise $\mathrm{Hb}>12 \mathrm{~g} / \mathrm{dL}$ and/or induce hypertension.

Oral iron preparations $\left(\mathrm{FeSO}_{4}\right.$, Niferex, Proferrin, etc.) may be sufficient to raise iron stores, though monthly IV iron supplementation may be required to ensure optimal erythropoiesis in patients with iron-deficiency anemia. Iron gluconate or iron sucrose are safer than iron dextran, which has been associated with anaphylaxis. Emerging IV iron agents are designed to minimize free iron and oxidative stress; an emerging oral iron agent utilizes the heme iron receptor in the gut for enhanced absorption.

Oral supplementation of folate, pyridoxine and vitamin $B_{12}$ (and other vitamins) is a rational choice in malnourished patients.

Not recommended.

$\mathbf{M C H}=$ mean corpuscular hemoglobin; $\mathbf{M C V}=$ mean corpuscular volume; $\mathbf{M C H C}=$ mean corpuscular hemoglobin concentration,

$\mathbf{H b}=$ hemoglobin; TSAT = serum transferrin saturation. 
It is essential to control hypertension before and during stimulated erythropoiesis [72,73]. Determination of serum ferritin and transferrin saturation is advised before initiation of erythropoietic therapy and every 1-3 months during therapy (Table 3) [16]. Patients with stable $\mathrm{Hb}$ in the target range who are receiving a stable dose of an erythropoietic agent should have their $\mathrm{Hb}$ checked monthly [16]. In iron-deficient patients, oral supplementation with inorganic iron salts may be sufficient, but more often parenteral iron is required in the form of iron gluconate or iron sucrose, which have supplanted iron dextran because of superior safety profiles. Physiologic levels of folate, vitamin $\mathrm{B}_{12}$, and pyridoxine can be maintained with oral supplementation.

\section{Conclusion}

Anemia, a clinical manifestation of reduced kidney function, is often underrecognized in patients with CKD. Substantial mortality and morbidity are associated with advanced CKD, and current evidence suggests that early proactive multimodal treatment can improve outcomes.

PCPs are uniquely positioned to screen at-risk patients for early CKD and anemia. In most patients, the severity of anemia can be easily reduced by use of erythropoietic agents and intravenous iron as necessary in the primary care setting. Monthly follow-up is required to evaluate general cardiorenal health and to ensure that $\mathrm{Hb}$ levels do not overshoot the optimal range of $11-12 \mathrm{~g} / \mathrm{dL}$, given current questions regarding the optimal $\mathrm{Hb}$ target. The burden of CKD and its complications is expected to continue to increase. With a shortage of nephrologists predicted, an expanded role for PCPs in the management of CKD and its attendant anemia may avert this potential public health crisis.

\section{Competing interests}

RJS: advisor or consultant - Roche, Ortho Biotech, Amgen

\section{CLD: speakers' bureau - Amgen}

\section{Authors' contributions}

RJS and CLD jointly participated in the article's conceptual development and multiple substantive revisions and approved the final version.

\section{Acknowledgements}

Article-processing charges and editorial services were funded by Roche. The authors acknowledge the editorial assistance of Kim Coleman Healy, $\mathrm{PhD}$, from Envision Pharma in the development of this manuscript. The funding source did not review or comment upon the manuscript; responsibility for content and interpretations rests with the authors. Envision Pharma supports Good Publication Practices Working Group and American Medical Writers' Association guidelines.

\section{References}

I. Drueke TB, Eckardt KU, Frei U, Jacobs C, Kokot F, McMahon LP, Schaefer RM: Does early anemia correction prevent complications of chronic renal failure? Clin Nephrol I999, 5 I: I-I I.

2. Nurko S: Anemia in chronic kidney disease: causes, diagnosis, treatment. Cleve Clin J Med 2006, 73:289-297.

3. McClellan W, Aronoff SL, Bolton WK, Hood S, Lorber DL, Tang KL, Tse TF, Wasserman B, Leiserowitz M: The prevalence of anemia in patients with chronic kidney disease. Curr Med Res Opin 2004, 20:150I-I5I0.

4. Hsu CY, McCulloch CE, Curhan GC: Epidemiology of anemia associated with chronic renal insufficiency among adults in the United States: results from the Third National Health and Nutrition Examination Survey. J Am Soc Nephrol 2002, 13:504-5 I0.

5. Walker AM, Schneider G, Yeaw J, Nordstrom B, Robbins S, Pettitt D: Anemia as a predictor of cardiovascular events in patients with elevated serum creatinine. J Am Soc Nephrol 2006, I 7:2293-2298.

6. Levin A, Singer J, Thompson CR, Ross H, Lewis M: Prevalent left ventricular hypertrophy in the predialysis population: identifying opportunities for intervention. Am J Kidney Dis 1996, 27:347-354.

7. Levin A, Thompson CR, Ethier J, Carlisle EJ, Tobe S, Mendelssohn D, Burgess E, Jindal K, Barrett B, Singer J, Djurdjev O: Left ventricular mass index increase in early renal disease: impact of decline in hemoglobin. Am / Kidney Dis 1999, 34: I25-134.

8. Khan SS, Kazmi WH, Abichandani R, Tighiouart H, Pereira BJ, Kausz AT: Health care utilization among patients with chronic kidney disease. Kidney Int 2002, 62:229-236.

9. Fink J, Blahut S, Reddy M, Light P: Use of erythropoietin before the initiation of dialysis and its impact on mortality. Am J Kidney Dis 200I, 37:348-355.

10. Revicki DA, Brown RE, Feeny DH, Henry D, Teehan BP, Rudnick MR, Benz RL: Health-related quality of life associated with recombinant human erythropoietin therapy for predialysis chronic renal disease patients. Am J Kidney Dis 1995, 25:548-554.

II. Clyne N, Jogestrand T: Effect of erythropoietin treatment on physical exercise capacity and on renal function in predialytic uremic patients. Nephron 1992, 60:390-396.

12. Lim VS, DeGowin RL, Zavala D, Kirchner PT, Abels R, Perry P, Fangman J: Recombinant human erythropoietin treatment in predialysis patients. A double-blind placebo-controlled trial. Ann Intern Med 1989, I I 0: 108-II4.

13. Besarab A, Soman S: Anemia management in chronic heart failure: lessons learnt from chronic kidney disease. Kidney Blood Press Res 2005, 28:363-37I.

14. Johnson CA, Levey AS, Coresh J, Levin A, Lau J, Eknoyan G: Clinical practice guidelines for chronic kidney disease in adults: Part I. Definition, disease stages, evaluation, treatment, and risk factors. Am Fam Physician 2004, 70:869-876.

15. K/DOQI clinical practice guidelines for chronic kidney disease : evaluation, classification, and stratification. Am J Kidney Dis 2002, 39:SI-266.

16. KDOQI Clinical Practice Guidelines and Clinical Practice Recommendations for Anemia in Chronic Kidney Disease. Am J Kidney Dis 2006, 47:SII-I45.

17. Fox CH, Brooks A, Zayas LE, McClellan W, Murray B: Primary care physicians' knowledge and practice patterns in the treatment of chronic kidney disease: an Upstate New York Practice-based Research Network (UNYNET) study. J Am Board Fam Med 2006, 19:54-61.

18. Arora P, Obrador GT, Ruthazer R, Kausz AT, Meyer KB, Jenuleson $C S$, Pereira BJ: Prevalence, predictors, and consequences of late nephrology referral at a tertiary care center. J Am Soc Nephrol 1999, I 0: I 28I-1286.

19. Zillich AJ, Saseen JJ, Dehart RM, Dumo P, Grabe DW, Gilmartin C, Hachey DM, Hudson JQ, Pruchnicki MC, Joy MS: Caring for patients with chronic kidney disease: a joint opinion of the ambulatory care and the nephrology practice and research networks of the American College of Clinical Pharmacy. Pharmacotherapy 2005, 25: | 23-143.

20. Arora P, Mustafa RA, Karam J, Khalil P, Wilding G, Ranjan R, Lohr J: Care of elderly patients with chronic kidney disease. Int Urol Nephrol 2006, 38:363-370. 
21. National Kidney Foundation - Kidney Early Evaluation Program: KEEP Annual Data Report 2006. Am J Kidney Dis 2007 , 49:SI-SI60.

22. Kiberd $B$ : The chronic kidney disease epidemic: stepping back and looking forward. J Am Soc Nephrol 2006, 17:2967-2973.

23. Gilbertson DT, Liu J, Xue JL, Louis TA, Solid CA, Ebben JP, Collins AJ: Projecting the number of patients with end-stage renal disease in the United States to the year 2015. J Am Soc Nephrol 2005, I6:3736-374I.

24. St Peter WL, Schoolwerth AC, McGowan T, McClellan WM: Chronic kidney disease: issues and establishing programs and clinics for improved patient outcomes. Am J Kidney Dis 2003, 41:903-924.

25. Shah N, Dahl NV, Kapoian T, Sherman RA, Walker JA: The nephrologist as a primary care provider for the hemodialysis patient. Int Urol Nephrol 2005, 37: I I3-II7.

26. Hunsicker LG: The consequences and costs of chronic kidney disease before ESRD. J Am Soc Nephrol 2004, I 5: I363-I 364.

27. Collins AJ, Li S, Gilbertson DT, Liu J, Chen SC, Herzog CA: Chronic kidney disease and cardiovascular disease in the Medicare population. Kidney Int Suppl 2003:S24-3I

28. Smith DH, Gullion CM, Nichols G, Keith DS, Brown JB: Cost of medical care for chronic kidney disease and comorbidity among enrollees in a large HMO population. J Am Soc Nephrol 2004, I5:1300-1306

29. KDOQI Clinical Practice Guideline and Clinical Practice Recommendations for anemia in chronic kidney disease : 2007 update of hemoglobin target. Am J Kidney Dis 2007, 50:47I-530.

30. Boulware LE, Troll MU, Jaar BG, Myers DI, Powe NR: Identification and referral of patients with progressive CKD: a national study. Am J Kidney Dis 2006, 48: 192-204.

31. Coresh J, Astor BC, Greene T, Eknoyan G, Levey AS: Prevalence of chronic kidney disease and decreased kidney function in the adult US population: Third National Health and Nutrition Examination Survey. Am J Kidney Dis 2003, 41:1-12.

32. Hsu CY, Vittinghoff E, Lin F, Shlipak MG: The incidence of endstage renal disease is increasing faster than the prevalence of chronic renal insufficiency. Ann Intern Med 2004, 141:95-101.

33. United States Renal Data System: Atlas of end-stage renal disease in the United States. Bethesda, MD: National Institutes of Health National Institute of Diabetes and Digestive and Kidney Diseases; 2003.

34. United States Renal Data System: Annual Data Report. Bethesda, MD: National Institutes of Health, National Institute of Diabetes and Digestive and Kidney Diseases; 2004.

35. United States Renal Data System: Annual Data Report. Bethesda MD: National Institutes of Health, National Institute of Diabetes and Digestive and Kidney Diseases; 2006.

36. Schoolwerth AC, Engelgau MM, Hostetter TH, Rufo KH, Chianchiano D, McClellan WM, Warnock DG, Vinicor F: Chronic kidney disease: a public health problem that needs a public health action plan. Prev Chronic Dis 2006, 3:A57.

37. Astor BC, Muntner P, Levin A, Eustace JA, Coresh J: Association of kidney function with anemia: the Third National Health and Nutrition Examination Survey (1988-1994). Arch Intern Med 2002, 162:140|-1408.

38. Eckardt KU, Mollmann M, Neumann R, Brunkhorst R, Burger HU, Lonnemann G, Scholz H, Keusch G, Buchholz B, Frei U, et al.: Erythropoietin in polycystic kidneys. J Clin Invest 1989, 84: I I60-I I66.

39. Pavlovic-Kentera V, Clemons GK, Djukanovic L, Biljanovic-Paunovic $\mathrm{L}$ : Erythropoietin and anemia in chronic renal failure. Exp Hematol 1987, 15:785-789.

40. Deicher R, Horl WH: Anaemia as a risk factor for the progression of chronic kidney disease. Curr Opin Nephrol Hypertens 2003 12:139-143.

4l. Donnelly S: Why is erythropoietin made in the kidney? The kidney functions as a critmeter. Am J Kidney Dis 200I, 38:4I5-425.

42. Hillege HL, van Gilst WH, van Veldhuisen DJ, Navis G, Grobbee DE, de Graeff PA, de Zeeuw D: Accelerated decline and prognostic impact of renal function after myocardial infarction and the benefits of ACE inhibition: the CATS randomized trial. Eur Heart J 2003, 24:41 2-420.
43. Avorn J, Bohn RL, Levy E, Levin R, Owen WF Jr, Winkelmayer WC, Glynn RJ: Nephrologist care and mortality in patients with chronic renal insufficiency. Arch Intern Med 2002, 162:2002-2006.

44. Felker GM, Adams KF Jr, Gattis WA, O'Connor CM: Anemia as a risk factor and therapeutic target in heart failure. J Am Coll Cardiol 2004, 44:959-966

45. Silverberg DS, Wexler D, Blum M, Keren G, Sheps D, Leibovitch E, Brosh D, Laniado S, Schwartz D, Yachnin T, et al.: The use of subcutaneous erythropoietin and intravenous iron for the treatment of the anemia of severe, resistant congestive heart failure improves cardiac and renal function and functional cardiac class, and markedly reduces hospitalizations. J Am Coll Cardiol 2000, 35: 1737-1744.

46. Silverberg DS, Wexler D, Blum M, Tchebiner JZ, Sheps D, Keren G, Schwartz D, Baruch R, Yachnin T, Shaked M, et al:: The effect of correction of anaemia in diabetics and non-diabetics with severe resistant congestive heart failure and chronic renal failure by subcutaneous erythropoietin and intravenous iron. Nephrol Dial Transplant 2003, 18:141-146.

47. Silverberg DS, Wexler D, Sheps D, Blum M, Keren G, Baruch R, Schwartz D, Yachnin T, Steinbruch S, Shapira I, et al.: The effect of correction of mild anemia in severe, resistant congestive heart failure using subcutaneous erythropoietin and intravenous iron: a randomized controlled study. J Am Coll Cardiol 2001, 37:1775-1780.

48. Go AS, Yang J, Ackerson LM, Lepper K, Robbins S, Massie BM, Shlipak MG: Hemoglobin level, chronic kidney disease, and the risks of death and hospitalization in adults with chronic heart failure: the Anemia in Chronic Heart Failure: Outcomes and Resource Utilization (ANCHOR) Study. Circulation 2006, I 1 3:27| 3-2723.

49. Muntner P, He J, Astor BC, Folsom AR, Coresh J: Traditional and nontraditional risk factors predict coronary heart disease in chronic kidney disease: results from the atherosclerosis risk in communities study. J Am Soc Nephrol 2005, 16:529-538.

50. Jurkovitz CT, Abramson JL, Vaccarino LV, Weintraub WS, McClellan WM: Association of high serum creatinine and anemia increases the risk of coronary events: results from the prospective community-based atherosclerosis risk in communities (ARIC) study. J Am Soc Nephrol 2003, I4:2919-2925.

51. Kovesdy CP, Trivedi BK, Kalantar-Zadeh K, Anderson JE: Association of anemia with outcomes in men with moderate and severe chronic kidney disease. Kidney Int 2006, 69:560-564

52. Mohanram A, Zhang Z, Shahinfar S, Keane WF, Brenner BM, Toto $R D$ : Anemia and end-stage renal disease in patients with type 2 diabetes and nephropathy. Kidney Int 2004, 66: I I3I-I I 38.

53. McCullough PA, Lepor NE: Piecing together the evidence on anemia: the link between chronic kidney disease and cardiovascular disease. Rev Cardiovasc Med 2005, 6(Suppl 3):S4-I2.

54. Ayus JC, Go AS, Valderrabano F, Verde E, de Vinuesa SG, Achinger SG, Lorenzo V, Arieff Al, Luno J: Effects of erythropoietin on left ventricular hypertrophy in adults with severe chronic renal failure and hemoglobin < 10 g/dL. Kidney Int 2005, 68:788-795.

55. Dean BB, Dylan M, Gano A Jr, Knight K, Ofman JJ, Levine BS: Erythropoiesis-stimulating protein therapy and the decline of renal function: a retrospective analysis of patients with chronic kidney disease. Curr Med Res Opin 2005, 21:98I-987.

56. Levin A, Djurdjev O, Thompson C, Barrett B, Ethier J, Carlisle E, Barre P, Magner P, Muirhead N, Tobe S, et al: Canadian randomized trial of hemoglobin maintenance to prevent or delay left ventricular mass growth in patients with CKD. Am J Kidney Dis 2005, 46:799-8II.

57. Roger SD, McMahon LP, Clarkson A, Disney A, Harris D, Hawley C, Healy H, Kerr P, Lynn K, Parnham A, et al.: Effects of early and late intervention with epoetin alpha on left ventricular mass among patients with chronic kidney disease (stage 3 or 4): results of a randomized clinical trial. J Am Soc Nephrol 2004 I5: | $48-156$

58. Gouva C, Nikolopoulos P, loannidis JP, Siamopoulos KC: Treating anemia early in renal failure patients slows the decline of renal function: a randomized controlled trial. Kidney Int 2004, 66:753-760.

59. Jungers P, Choukroun G, Oualim Z, Robino C, Nguyen AT, Man NK: Beneficial influence of recombinant human erythropoietin therapy on the rate of progression of chronic renal failure in predialysis patients. Nephrol Dial Transplant 200I, 16:307-3I2. 
60. Singh AK, Szczech L, Tang KL, Barnhart H, Sapp S, Wolfson M, Reddan $D$ : Correction of anemia with epoetin alfa in chronic kidney disease. N Engl J Med 2006, 355:2085-2098.

61. Drueke TB, Locatelli F, Clyne N, Eckardt KU, Macdougall IC, Tsakiris D, Burger HU, Scherhag A: Normalization of hemoglobin level in patients with chronic kidney disease and anemia. N Engl J Med 2006, 355:207I-2084.

62. Locatelli F, Del Vecchio L, Pozzoni P: Anemia and cardiovascular risk: the lesson of the CREATE trial. J Am Soc Nephrol 2006, I 7:S262-S266

63. Besarab A, Bolton WK, Browne JK, Egrie JC, Nissenson AR, Okamoto DM, Schwab SJ, Goodkin DA: The effects of normal as compared with low hematocrit values in patients with cardiac disease who are receiving hemodialysis and epoetin. $N$ Engl J Med I998, 339:584-590.

64. Eschbach JW, Abdulhadi MH, Browne JK, Delano BG, Downing MR, Egrie JC, Evans RW, Friedman EA, Graber SE, Haley NR, et al: Recombinant human erythropoietin in anemic patients with end-stage renal disease. Results of a phase III multicenter clinical trial. Ann Intern Med 1989, I I I:992-1000.

65. Roth D, Smith RD, Schulman G, Steinman TI, Hatch FE, Rudnick MR Sloand JA, Freedman BI, Williams WW Jr, Shadur CA, et al.: Effects of recombinant human erythropoietin on renal function in chronic renal failure predialysis patients. Am J Kidney Dis 1994, 24:777-784.

66. Rossert J, Levin A, Roger SD, Horl WH, Fouqueray B, GassmannMayer C, Frei D, McClellan WM: Effect of early correction of anemia on the progression of CKD. Am J Kidney Dis 2006, 47:738-750

67. Cody J, Daly C, Campbell M, Donaldson C, Khan I, Rabindranath K, Vale L, Wallace S, Macleod A: Recombinant human erythropoietin for chronic renal failure anaemia in pre-dialysis patients. Cochrane Database Syst Rev 2005:CD003266.

68. Aranesp(R)[US prescribing information]. Thousand Oaks, CA : Amgen, Inc; 2007.

69. Epogen(R) [US prescribing information]. Thousand Oaks, CA : Amgen, Inc; 2007.

70. Thomas MC, Cooper ME, Rossing K, Parving HH: Anaemia in diabetes: Is there a rationale to TREAT? Diabetologia 2006 49: II5I-II57.

71. Pfeffer MA: An ongoing study of anemia correction in chronic kidney disease. N Engl J Med 2007, 356:959-96I.

72. Public Health Advisory : Epoetin alfa (marketed as Procrit, Epogen), Darbepoetin alfa (marketed as Aranesp) [http:// www.fda.gov/cder/drug/advisory/RHE.htm]

73. Information for Healthcare Professionals : Erythropoiesis Stimulating Agents (ESA) [Aranesp (darbepoetin), Epogen (epoetin alfa), and Procrit (epoetin alfa) [http://www.fda.gov/ cder/drug/InfoSheets/HCP/RHE2007HCP.htm]

74. Rossert ], Froissart $M$, Jacquot C: Anemia management and chronic renal failure progression. Kidney Int Suppl 2005:S76-8I.

75. Nissenson AR: Epoetin and cognitive function. Am J Kidney Dis 1992, 20:2I-24.

76. Moreno F, Sanz-Guajardo D, Lopez-Gomez JM, Jofre R, Valderrabano $F$ : Increasing the hematocrit has a beneficial effect on quality of life and is safe in selected hemodialysis patients. Spanish Cooperative Renal Patients Quality of Life Study Group of the Spanish Society of Nephrology. J Am Soc Nephrol 2000, I I:335-342.

77. Mancini DM, Katz SD, Lang CC, LaManca J, Hudaihed A, Androne AS: Effect of erythropoietin on exercise capacity in patients with moderate to severe chronic heart failure. Circulation 2003 , 107:294-299.

78. Silverberg DS, Wexler D, Blum M, laina A, Sheps D, Keren G, Scherhag $A$, Schwartz D: Effects of treatment with epoetin beta on outcomes in patients with anaemia and chronic heart failure. Kidney Blood Press Res 2005, 28:4l-47.

79. Kuriyama S, Tomonari H, Yoshida H, Hashimoto T, Kawaguchi $\mathrm{Y}$, Sakai O: Reversal of anemia by erythropoietin therapy retards the progression of chronic renal failure, especially in nondiabetic patients. Nephron 1997, 77:176-185.
Publish with Biomed Central and every scientist can read your work free of charge

"BioMed Central will be the most significant development for disseminating the results of biomedical research in our lifetime. "

Sir Paul Nurse, Cancer Research UK

Your research papers will be:

- available free of charge to the entire biomedical community

- peer reviewed and published immediately upon acceptance

- cited in PubMed and archived on PubMed Central

- yours - you keep the copyright
BioMedcentral 